\title{
THE EKO-TEOCRACY CONCEPT IN DISPOSAL SETTLEMENT OF OIL POLLUTION IN THE SEA BY TANKER SHIP
}

\section{Elly Kristiani Purwendah}

\author{
Fakultas Hukum \\ Universitas Wijayakusuma Purwokerto \\ Email : elly_kristiani@yahoo.co.id
}

\begin{abstract}
The shift in the Eco-Theocratic thinking in resolving oil pollution disputes at sea by tankers is intended as a new paradigm reconstruction that is more oriented to deep ecology with an ecoliteracy perspective towards a new ecodesign environment as an equal subject to human beings resisting anthropocentrism toward society sustainable sociaty and sustainable environmental development. This concept was built through an analysis of the shift in the perspective of philosophical figures from the organic paradigm of nature to the mechanistic paradigm of new nature and paradigms in looking at nature systemically, holistically and ecologically. This new ecoliteracy paradigm is analyzed through a system of democracy, ecocracy and theocracy with a measure of theology and paradigm of the Pancasila.
\end{abstract}

Keywords: Eco-theocracy, ecoliteracy, deep ecology, anthropocentrism, dispute resolution, oil pollution

\begin{abstract}
Abstrak
Pergeseran pemikiran Eko-Teokrasi dalam penyelesaian sengketa pencemaran minyak di laut oleh kapal tanker dimaksudkan sebagai sebuah rekonstruksi paradigma baru yang lebih berorientasi pada deep ecology dengan cara pandang ecoliteracy menuju sebuah ecodesign baru lingkungan hidup sebagai subyek hukum yang setara dengan manusia meresistensi cara pandang antroposentrisme menuju masyarakat sustainable sociaty dan pembangunan lingkungan hidup berkelanjutan. Konsep ini dibangun melalui analisis pergeseran cara pandang tokoh-tokoh filsafat dari paradigma organis tentang alam menjadi paradigma mekanistis tentang alam dan paradigma baru dalam memandang alam secara sistemis, holistis dan ekologis. Paradigma baru ecoliteracy ini dianalisis melalui sistem demokrasi, ekokrasi dan teokrasi dengan alat ukur teologi dan paradigma Pancasila.
\end{abstract}

Kata kunci : Eko-teokrasi, ecoliteracy, deep ecology, antroposentrisme, penyelesaian sengketa, pencemaran minyak 


\section{Introduction}

Environmental crisis or environmental ecology is understood through a paradigm or approach to the environment that is more profound through the concept of deep ecology. The evolving paradigm of how the environment is viewed at the level of life is very dependent on understanding which sometimes has a crisis of understanding (Thomas Khun) which comes from the fact that most of us in particular our large social institutions adhere to outdated perspectives. An understanding of reality that is no longer sufficient to understand our densely populated world and relate to one another globally. Paradigms that are not systemic, organizational, holistic and ecological result in inappropriate approaches to environmental problems.

The environment that is not seen as a legal subject in the way of the field of egocentrism (anthropocentric) still places man as the central ruler of nature. In the starting point of understanding the simplest democracy is defined as the government of the people, by the people and for the people. This understanding is not without problems, the people's words actually contain very complex understanding. At least there are some problems, first, when people are assumed to be a collection of people, it will lead to the essence of humans as individuals and humans as a group of individuals and what kind of relationship between individuals and society. Variations in answers to these questions will determine what kind of justice will be pursued and which path will be taken. Henceforth, it can be mixed in the concept of environmental philosophy about how justice that has been agreed upon by society positions nature or its environment.

This study is so important considering that democracy is essentially in placing justice still in the discussion of society which is a group of individuals as subjects and the environment as objects of community support. This situation affects the way in which environmental disputes are resolved which negate the environment as a legal subject, in contrast to the Ecuadorian state which places the environment as the legal subject in its constitution. ${ }^{1}$ Indonesia places the environment as the legal subject only at the practical level through the concept of legal standing or standing to sue through NGOs.

This concept certainly affects the outcome of environmental dispute resolution, especially in this case the resolution of sea pollution disputes by tankers. Pollution cases that occur see the main victims of pollution are human beings, the environment has not become an immediate victim interest, this solution approach still uses the mechanistic paradigm and understanding of, by and for the people is not based on the marine environment.

This paper is expected to be able to examine a reconstructive approach to resolving oil pollution disputes by tankers through an eco-theocratic approach in the Pancasila paradigm through environmental philosophy that is systemic, organizational, holistic and ecological paradigm. Understanding of democracy in the paradigm of modern environmental philosophy has led to the resolution of sea

Boris Dewiel, 2000, Democracy, A History of Ideas, UBC Press. Hal. 11-22. 
pollution disputes by tankers not oriented to the marine environment. The concept of deep ecology has not become a concept of dispute resolution, the concept of anthropocentrism in the existing democratic level inhibits ecolithicacy. The Pancasila perspective of eco-theocracy through an ecoliteracy approach as an option to resolve oil pollution disputes at sea by tanker ships should be studied in depth to produce a new pattern in green law enforcement.

\section{Literature Review}

\subsection{Antoposentrism in the Environment}

In the discourse on environmental ethics there are two main theories, namely anthropocentrism and ecocentrism. Antropocentrism places man as the center of the universe system. Humans and their interests are seen as the most decisive in the ecosystem order and in all policies taken are related to nature, both directly and indirectly. Everything else in the universe will only get value and attention to the extent that it supports and in the interest of humans.

Therefore nature is only seen as an object, tool, and means for fulfilling human needs and interests. Nature is only a tool for achieving human goals. ${ }^{2}$ Anthropocentrism has so far still been a dominant feature in the mindset of the people. This is in line with Thomas Khun's thinking, which divides three phases into two important changes in the paradigm of history in philosophy and science.

The induction method totally changes the purpose of knowledge. The aim of science (and philosophy) is to understand wisely the order of the universe and live in harmony with nature, under the Bacon method is to dominate and master nature. Knowledge is power, knowledge is power, with science and technology humans dominate the universe, change and make it the object of satisfying the needs of human life.

The ability of reason and rational science that is controlled by humans makes it possible for one side to view nature as an inanimate object, as a machine to be analyzed into its parts. On the other hand it also allows humans to be aggressive and exploitative without feeling and respect for the universe. Domination, power, control are the main patterns of relations between humans and nature.

According to Capra, our science and technology which is based on 17th century belief in understanding nature means mastering and dominating nature by male humans (man), combined with a mechanistic model of the universe that also began in the 17th century, accompanied by emphasis Excessive linear thinking has shaped attitudes and behaviors that give rise to unhealthy and inhuman technology, the main purpose of which is control, mass production and standardization. ${ }^{3}$ That is the root of all these global environmental disasters and crises. It is this attitude of behavior that gives birth to various policies, practices and patterns of life that damage and destroy the environment with all the associated impacts including ultimately destroying life, including human life.

A. Sony Keraf, 2002, Etika Lingkungan, Kompas, Jakarta. Hal. 33. Fritjof Capra, The Turning Point, op. cit. Hal.2. 
This mechanistic phase has the anthropocentrism characteristic that inspired various ideas about modernity. Like W.W. Rostow on the theory of economic growth (The Stages of Economic Growth) which assumes that social change assumed as development is an evolutionary process that runs linearly from traditional to modern. In Rostow's concept, industry is the main backbone and high mass consumption is used as the main marker that the society can be categorized as modern and not. ${ }^{4}$ On the other hand, an increase in industry and community consumption will give an increasing burden on the environment.

The need for technology requires fuels that exploit natural resources, with very high vulnerability both time that does not take into account future generations, and its impact on nature in the event of pollution both on land, sea and air.

In modern society, industrialization is indeed the economic driving force for achieving prosperity and prosperity. Therefore industrialization plays a very central role in the development process, but without realizing it, the existence of the industry itself creates a double effect for society. On the one hand the existence of industry extends the benefits of natural resources but on the other hand industrialization also has a negative impact. As reported by the World Commission on Environment and Development which impacts on the natural resource base through the entire cycle of exploration and ecstasy for raw goods, transformation into products, energy consumption, production waste and product use along with waste disposal produced from these products by consumers. ${ }^{5}$ Industrialization has forced nature to accommodate all the residue from its activities in the form of garbage and waste, as a result of which nature becomes polluted and the quality of the environment decreases. For example, pollution that occurs due to the operation of tankers is estimated at $75 \%$, while the consequences of ship accidents are only $25 \%$ of the total pollution that occurs. ${ }^{6}$ Oil is a priority sector in the carrying capacity of modern people's lives and contributes to the damage to the world's marine environment.

Overcoming the above perspective requires a new perspective with friendly behavior and attitudes, caring for nature and the environment that emerge from a combination of rational abilities and knowledge on the one hand and intuitive experiences of the universe and the environment on the other. An attitude and behavior that gives a place as central to human feelings and intuition as the role of human reason. This friendly behavior with nature is based on a paradigm and a new perspective on the universe as a whole system that is integrated and intertwined with one another. A holistic and ecological new perspective on the universe because it understands that humans are only one entity in the whole universe. An attitude and behavior that comes from a basic understanding that human beings are not first

\footnotetext{
$4 \quad$ Mansour Fakih, 2006, Runtuhnya Teori Pembanguna dan Globalisasi, Kerjasama Insist Press dan Pustaka Pelajar, Yogyakarta. Hal. 55-56.

5 Komisi Dunia untuk Lingkungan Hidup dan Pembangunan (World Commissions on Environmental and Development), 1988, Hari Depan Kita Bersama, Gramedia, Jakarta. Hal. 285.

6 Griffin, Andrew, 1994, Marpol 73/78 and Vessel Pollution: a Glass Half Full or Half Empty ?, Indiana Journal of Global Legasl Studies. Hal. 1.
} 
as social beings, but as ecological beings, creatures that cannot develop into their whole being without ecosystems and without relation to the whole ecosystem. Hacking the concept of anthropocentrism through the Pancasila Eco-Theocracy in the Approach to Environmental Problems

The concept of state sovereignty includes two contexts of understanding, namely internal and external understandings. In the internal sense, sovereignty as the highest concept of power known so far in the world of legal and political philosophy includes the teachings on God's sovereignty (theocracy), democracy, law sovereignty (nomocracy), and monarchy.

Of the four concepts of supreme power or sovereignty, the 1945 Constitution adheres to at least two teachings explicitly namely popular sovereignty and legal sovereignty relating to the idea of democracy and the rule of law. Even in a different sense from the classical conception of theocracy. The 1945 Constitution recognizes the existence of the highest principle of power that comes from God the Almighty. The consequences of the concepts of the theocracy implied in the 1945 Constitution inspire the lives of Indonesian people that, the great power of a country is in a godly society. This concept gives a religious burden on the level of superiority of society in a democratic order patterned in anthropocentrism. Even though democracy is etymologically understood as a means to justice, the style of anthropocentrism in the concept of democracy is very dominant because it is oriented to the interests of the people.

Democracy is understood as a way to assert people's authority vis-a-vis individuals because individuals cannot live independently of society. Justice aspired is social justice and distributive justice. The state has an important and more active role. Human rights are not understood as freedom but as rewards that can be accepted by individuals in their role as society (entitlement). One of the estuaries of this understanding is the formulation of social, economic and cultural rights. For this camp, human rights interpreted as freedom are the rights of the bourgeoisie or elite, because they can only be realized by people who are full, healthy and educated.

In the state level the style of democracy is so thickly reflected in the system of Indonesian government. Understanding indicates that democratic forms of government are considered to improve environmental quality through good environmental governance. ${ }^{7}$ In a democracy the mechanism of managing togetherness and control by power is given by the state, in the sense that the mechanism or system of individual participation in the joint decision-making process rests on the principle of equality.

The philosophical issue at the level of democracy is whether what is sought as a common interest can be realized as truly a common interest or only compromises through various representations of common interests through individuals who represent the interests of the people? Philosophical questions such as this require a very philosophical answer through the understanding of nature or cosmic mechanistic level and the concept of anthropocentrism in a democracy

Quan Li dan Rafael Reuveny, 2006, Democracy and Environmental Degradation International Studies Quarterly. Hal. 935-956. 
interpreted by humans as a cosmic peak, as the subject that moves mechanically the environment, ecology and universe through manifested sovereignty through the legitimacy of democratic supremacy .

This condition is of course a scourge of people's treatment of their environment considering that in terms of the constitution, Indonesia can be categorized as a moderate commitment. ${ }^{8}$ In the case of constitutionalisation of environmental legal norms by looking at, 1). Subjective right recognition in environmental management as stipulated in Article $28 \mathrm{H}$ paragraph (1) of the 1945 Constitution; 2). Recognition that environmentally sound elements are an important element in the national economy as mentioned in Article 33 paragraph (4) of the 1945 Constitution. This article is referred to as a green constitution, stating that, "The national economy is organized based on economic democracy with the principle of togetherness, efficiency of justice, sustainable, environmentally sound and by maintaining a balance of progress and unity of the national economy ".

This article is still focused on the concept of human justice, central to sustainable development in the environment still in human power. The 1945 Constitution is still half-hearted in protecting the interests of the environment as its own legal subject. ${ }^{9}$ This means that the Indonesian constitution still recognizes limited subjective rights that are anthropocentric, yet explicitly declares environmental rights as the subject of law. ${ }^{10}$

Extreme ideologies that will latently tempt humans, that ideology is the ideology of anthropocentrism, ${ }^{11}$ which places man as the center of interests and

8 Mas Achmad Santosa, 2009, dalam Pengantar Jimly Asshidiqqie, Green Constitution: Nuansa Hijau Undang-undang Dasar Negara Republik Indonesia Tahun 1945, Rajawali Press, Jakarta.

$9 \quad$ Lihat Mas Achmad Santosa, Greener Conctitution: Solusi Pengarusutamaan Pembangunan Berkelanjutan, dalam Iwan J. Azis, et al. (Ed.), 2010, Pembangunan Berkelanjutan: Peran dan Kontribusi Emil Salim, Gramedia. Hal. 125-150. Komitmen tertinggi merupakan pengakuan yang lengkap atas hak hukum untuk alam (the right for the nature), hak-hak subjektif, kewajiban negara serta arah pembangunan. Komitmen tinggi hampir sama dengan katagori pertama minus the right for the nature. Pendekatan katagori kedua masih antroposentris. Komitmen memadai mengakui hak-hak subyektif dan kewajiban negara dalam pasal-pasal khusus dan tersenbdiri (tidak dicampur aduk dengan hak-hak lain). Komitmen sedang memberikan pengakuan hak subyektif tanpa mengakui kewajiban negara namun memberikan arah pada pola pembangunan nasional. Hak subyektif dan arah pembangunan tidak diatur secara spesifik tetapi digabung dengan hak-hak lainnya. Sedangkan pada katagori komitmen rendah konstitusi sama sekali tidak mengakui norma hukum lingkungan (hak subyektif maupun kewajiban negara), maupun pengakuan pola dan arah pembangunan berkelanjutan.

10 Mas Achmad Santosa, 2009, dalam Pengantar Jimly Asshidiqqie, Green Constitution: Nuansa Hijau Undang-undang Dasar Negara Republik Indonesia Tahun 1945, Rajawali Press, Jakarta.

11 Erri N. Megantara, Pendekatan Pembangunan Antroposentris vs Ekosentris, Koran Republika, 11 Januari 1997. Dalam pendekatan antroposentris, seringkali dianggap posisi manusia berada diluar dan terpisah dari lingkungannya. Lingkungan keberadaannya hanya diperuntukkan untuk kepentingan manusia, sehingga seringkali yang terjadi adalah kelalaian dalam memeliharanya. Untuk mengatasi pendekatan yang terlanjur mengakar pada tatanan masyarakat secara luas, maka diperlukan suatu pendekatan yang komprehensif yang dapat menyatukan antara manusia dan lingkungan. Pendekatan ini lazim disebut dengan pendekatan ekosentrisme. 
interests focused and reduced to physical interests, so that what emerges is economism and technology. Economism (with capitalism as its peak) will place economic interests namely profit or profit for humans as a focus supported by technology.

In the context of democracy it is necessary to renew the perspective of environmental law, which is inseparable from rule of law as one of the key elements of democracy. In the context of the rule of law five key elements are, 1). legal certainty; 2). Independent judiciary; 3). Effective law enforcement; 4). Establishment of participatory legislation; 5). Access to justice, especially for marginalized and disadvantaged people.

The good relationship between democracy and environmental governance is interpreted as community participation in equitable environmental management, ${ }^{12}$ then the movement for renewal of environmental law in Indonesia is the starting point in understanding the role of society in the current structure of environmental law.

On a global scale the views of Vandana Shiva presented in 2005 on earth democracy are said in the contemporary context to reflect the values, world views and actions of various movements that work for peace, justice and sustainability. The combination of representative democracy and economic globalization has given birth to new fears, new concerns, new fundamentalists and new violence. ${ }^{13}$ Ten earth democracy principles, ${ }^{14}$ even though it is classified as representing deep ecology, it can be analyzed to be seen in the context of developing Indonesian environmental law. These principles include the intrinsic value of each species, the diversity and interconnection of the earth, to living economy and economic democracy. Koesnadi Hardjasoemantri Indonesia's environmental law figure plays a major role in the development of environmental law, especially in terms of community participation in environmental decision making. ${ }^{15}$ His most prominent and relevant thinking with good environmental governance in democracy is the importance of community participation in making decisions related to the environment and natural resources.

The thoughts of the leaders of Indonesian environmental law began to show the stretch of the economy through the thought of Munadjat Danusaputr, ${ }^{16}$ who

12 Vandana Shiva, 2005, Earth Democracy: Justice, Sustainablity, and Peace, South End Press, Cambridge. Hal. 7-11.

13 Boris Dewiel, What is the People? A Conceptual History of Coneptual History of Civil Society, op. cit., Hal. 11-12.

14 Vandana Shiva, Earth Democracy: Justice, Sustainablity, and Peace, op. cit. Hal. 10-11. 1). Nilai intrinsik setiap spesies, manusia dan budaya; 2). Komunitas bumi sebagai demokrasi dari semua kehidupan; 3). Harus dipertahankan keanekaragaman budaya dan alam; 4). Hak natural semua kehidupan untuk lestari; 5). Berlandaskan living economi dan economic democracy; 6). Living economies dibangun diatas ekonomi lokal; 7). Earth democracy dilandaskan pada living culture; 9). Living culture yang berkarakter life nourishing; 10). Earth democracy mengglobalkan kedamaian, perhatian dan kasih.

15 Pemikiran Koesnadi terutama terlihat dalam UU Lingkungan Hidup 1982, bersama dengan Emil Salim, Mochtar Kusumaatmadja, dan Otto Soemarwoto.

16 Mukhlish dan Mustafa Lutfi, 2011, Ekologi Konstitusi: Antara Rekosntruksi, Investasi atau Eksploitasi atas Nama NKRI, Jurnal Mahkamah Konstitusi, Vol. 8 No. 3. Hal. 196. 
said that environmental law that views the environment as an object is a law that looks at the use and utilization of environmental resources to the maximum extent possible in various ways and means to ensure its usefulness. Then this view shifts by making the environment a legal subject. With the view of law as a subject, environmental law focuses its function as a rational management system of environmental management and preserves its resources in such a way that it prevents quality depreciation and deterioration.

Democracy must be seen as being responsible for the wave of environmental damage and the ecosystem of the world today. Although democracy itself does not need to be antagonized but its development in the future must be controlled by law balanced by a new concept called the ecocracy. In the concept of ecocracy, the natural environment, like humans, is considered to have its own autonomy and sovereignty. If in a democracy every human being called the people is considered the holder of the highest sovereignty or power, then the natural environment is also seen as having its own human rights and holding its own sovereignty like humans.

In fulfilling the right of environment in the context of deep ecology, there has actually been recognition in legislation in Indonesia (Article 92 of the UUPPLH on legal standing / NGOs) that it cannot be said that the recognition of environmental rights as legal subjects has become a truly established legal ideas in Indonesia.

Jimly asshiddiqie, ${ }^{17}$ explains how the development of efforts to constitute pro-environment policies in history culminating in the adoption of the "Charter for Environment" document (2004) added to the French Preambule Constitution material in 2006, and published the idea of environmental sovereignty in the Ecuadorian Constitution in 2008. According to the Ecuador Constitution, ${ }^{18}$ in addition to human status as a people, the environment can also be the holder of his own rights and powers. These environmental rights and powers are of the same height as the rights and powers of the people, in other words, can be the subject of separate sovereignty. Because if the highest power which is in the hands of the people is referred to as democratic sovereignty of the people, then the highest power that exists in the environment can we call ecocracy or environmental sovereignty.

The idea of eco-democracy and environmental sovereignty can be developed as a counterweight to the demoration system developed by humanity everywhere today. The concept of ecocracy is understood in the context of the balance of relations between God, Nature and humans. Ecocracy is ecocentric for that according to Jimly Asshiddiqie, ${ }^{19}$ in a life that is all secular and positivistic it is necessary to reconsider the presence of God in the human perspective on nature and the environment. In the pattern of the relationship between humans and the surrounding environment and even with a whole nature that is balanced and mutually balanced, it is necessary to have a theocentric perspective that views God as the center of all human and natural life.

\footnotetext{
${ }^{17}$ J imly Asshiddiqie, 2009, Gagasan Kedaulatan Lingkungan: Demokrasi Versus Ekokrasi, disarikan dari materi buku, Green Constitution: Nuansa Hijau UUD 1945, Rajagrafindo/Rajawali Press, Jakarta.

18 Jimly Asshiddiqie, Ibid.

19 Jimly Asshiddiqie, Ibid.
} 
It is the triangular relationship between God, nature and humans that can guarantee a balanced pattern of relations between humans versus nature, between anthropocentrism versus ecocentrism, between democracy and the economy, then between ecoration and theocracy.

The importance of God's presence in the view of modern humans today, as said by Wendell Berry, "our ecological crisis is a crisis of character of political or social crisis". Therefore according to Preston Bristow, the problem concerns the issue of spirituality. According to him, "The religion of consumerism is a spiritual problem and we must fight fire with fire. Spiritual problems require spiritual solutions ". That is why understanding God's sovereignty must be included in paradigmatic studies to solve environmental damage caused by patterns of unequal relations between humans and nature.

The concept of state sovereignty as the idea of the highest authority (concept of sovereignty) we recognize the Sovereignty of God which is referred to by the Theocracy. The eco-theocracy offered in this paper tries to rest on the Pancasila perspective through its causalis theory in its scientific analysis of the nature of the relationship between God and humans, Notonagoro (1971) concludes, ${ }^{20}$ that God Almighty is causa prime, motor immobilis, sangkan paraning dumadi; meanwhile the essence of man as a creature of God YME is composed of monopluralists, sarwa singular (soul-body, individual-social, male-female, etc.) which in its entirety and wholeness are active in order to fulfill humanitarian needs which lead to perfection (absolute, absolute). Pancasila as a nation's view of life in an NKRI offers a very clear concept of theocracy, especially as the whole unit in its five principles affirms the transcendental relations that characterize the five principles so as to produce the concept of theocracy in its national life as absolute values.

This concept encompasses how the nation looks at individual rights, collective rights which include individual relations with society, individual relations or society with their nature, in the whole frame of state sovereignty in seeking the values of truth and justice that are essential. God Almighty has granted the values of truth and justice to the Indonesian people. These divine values have become a source of inspiration and motivation for the emergence of other values. Philosophically it is said that every value must be sourced and imbued by the value of God Almighty. Such necessity brings the Indonesian people together as a whole system called the value system. That value system was later known as the Pancasila.

Law is a paradigm of Pancasila ${ }^{21}$ is a category of legal science that is typical of Indonesia, but objective-universal. This law pivots from God Almighty. This law is full of divine values and other values in the frame of the value of YME Godhead.

20 Sudjito, 2013, Hukum dalam Pelangi Kehidupan, edisi revisi, Tugu Jogja Pustaka, Jogjakarta. Hal. 25-26.

21 Sudjito, Ibid. Hal. 26. Hasil dari proses perburuan kebenaran hakiki atas tiga hal (manusia, alam serta Tuhan YME) tersebut akan melahirkan apa yang di dalam ilmu disebut paradigma. Paradigma itulah yang menentukan nilai-nilai teleologis, filosofis maupun ideologis yang dianutnya. Lebih lanjut dikatakan, paradigma sebagai seperangkat nilai (tentang Tuhan, alam dan manusia, dan hubungan diantara ketiganya) yang diyakini kebenarannya dan hukumhukum serta teknik-teknik aplikasi yang dianut bersama oleh para anggota suatu komunitas ilmiah. 
For the Indonesian people, theology is part of Indonesian law. Theology here is not just a discipline that studies divinity, is astringent, normative and scholastic but rather as an interpretation of reality in a Godhead perspective. Humans of Indonesia are aware of the nature of their humanity, namely as intelligent beings, the understanding of the values of God, religion and theology is not based on dogma, force or pressure but is a rational understanding.

\subsection{Eco-theocracy of the environment is a Pancasila perspective in cases of marine pollution by tankers}

The Eko-Theocracy concept paradigmatic of the Pancasila that the writer is trying to offer in this paper reviews a few developers of ideas about the concepts of ecocracy and theocracy in a grand grand design namely ecoliteracy or ecological literacy, as expected in the level of deep ecology and ecodesign especially in the concept of legal sovereignty through an interpretation of basic law (state constitution) that places the environment as a legal subject.

Eco-Theocracy The paradigm of Pancasila is intended to offer the right key to open up the problem of pollution of the marine environment due to oil by tankers, as research conducted by the author in 2004 on oil contamination in the cilacap by the King Fisher tanker. ${ }^{22}$ The approach used in problem solving uses a democratic approach oriented to anthropocentrism by placing human interests as a priority.

The Eco-Theocratic concept offered in this paper is framed through the Pancasila paradigm that is specifically characterized by Indonesia and Indonesian character so that it is expected to fulfill causa materialis because it is a custom, culture and religion of the Indonesian people so that it is expected to be a key to elaborating individual-community religious values countries to choose the approach to protect the marine environment through the essence of transcendental justice. So that the marine environment in this case becomes an important subject equivalent to other subjects, namely humans both individually and collectively, in the state sovereignty level.

The Eco-Theocracy concept with the Pancasila paradigm is very much needed considering that modern society needs oil in its life support capacity. Oil transportation is important for the world economy and is a big business. The transportation of oil by sea is estimated at $40 \%$ of all trade transported by sea. Sea transportation facilities are dominated by tankers which are estimated to be more than 400 super tankers sail every day. The ships annually spill one to two million tons of oil in the marine environment. Oil spills into the sea are caused by the operation of ships, ship accidents resulting in a decrease in the quality of the marine environment.

This was stated in the results of research by Larissa Dsikowitzky, Inga Nordhaus, Team C Jennerjhan, Polina Khrycheva, Yoganathan Sivatharshan, Edy

22 Nita Triana, Elly Kristiani P, 2004, Alternative Dispute Resolution/ADR (Pelaksanaan Penegakan Hukum Lingkungan Dengan Konsep ADR Dalam Kasus Pencemaran Laut Oleh Kapal King Fisher, Penelitian Dosen Muda, DIKTI. 
Yuwono, Jan Schwarzbauer ${ }^{23}$, with the title "Anthropogenic organic contaminants in water, sediment and benthic organisms of the mangrove fringed Segara Anakan Lagoon Java, Indonesia". In his conclusion stated that, "Our findings suggest that more attention should be paid to the risk potential of alkylated PAHs, which has hardly been addressed previously".

Oil pollution problems originating from tanker waste due to ship cleaning activities have not been an important concern in marine law enforcement practices so far. Because the legal structure is still fixed on the concept of anthropocentrism democracy where the center of law enforcement is on the subject of individual law, society as a collection of individuals, and the state. The legal structure has not been environmentally oriented as a legal subject (ecocracy) and has not seen that the enforcement of environmental law as a legal substance hierarchically refers to a legal dogmatic namely Pancasila with its philosophical theology and passed through the constitution (UUD 1945) to theocracy with legal meaning, law and law enforcement becomes not value-free, but full of value, absolute value, absolute.

\section{Conclusion}

Philosophical analysis is carried out to unravel the problems of high environmental crises that have so much affected modern society by way of scientific mechanism (the dominance of Rene Descartes's way of thinking) that only sees the environment as mechanistic nets so that humans are seen as centric life (egocentric anthropocentrism). The democracy that has been embraced by the State is inseparable from the weakness of the perspective that humans are centrist and legal subjects without placing the position of the environment as a legal subject. The Eco-Theocracy concept paradigmatic of Pancasila becomes an urgent need to immediately reconstruct the concept of democracy by placing the human environment as a legal subject equal to humans. The perspective of the environment as a legal subject becomes a new ecological literacy, leading to forming public awareness of the importance of the environment for the sustainability of the web of life. Ecoliteracy as a knife of analysis is used to peel off the Indonesian democratic system in a main rationale as a state philosophy, namely the Pancasila paradigm so as to produce a unique Eco-Theocratic concept characterized by Indonesia. Reflection on this concept is expected to be a priority thinking that the environment needs to be accommodated as a legal subject in the basic law of the State / constitution, so that the perspective on the environment becomes more systemic, organizational, holistic and ecological. This perspective will of course have a profound effect (as an ecodesign) on legal culture, legal substance, and ecoliteracy legal structure, so that oil pollution cases in the marine environment by tankers can be resolved through sea orientation as equal legal subjects with other legal subjects, namely humans.

23 Leibniz Center for Tropical Marine Ecology (ZMT), Fahrenheitstraße 6, 28359 Bremen, Germany., Marine pollution bulletin (Impact Factor: 2.63). 03/2011; 62(4):851-62. 


\section{References}

Andrew, Griffin, , 1994, Marpol 73/78 and Vessel Pollution: a Glass Half Full or Half Empty?, Indiana Journal of Global Legasl Studies.

Asshiddiqie, Jimly, 2009, Gagasan Kedaulatan Lingkungan: Demokrasi Versus Ekokrasi, disarikan dari materi buku, Green Constitution: Nuansa Hijau UUD 1945, Rajagrafindo/Rajawali Press, Jakarta.

Capra, Fritjof, 1983, The turning Point. Science, Society and Rising Culture, London, Flaminggo.

CD, Stone., 1972, Should Trees Have Standing? Toward Legal Rights for Natural Objects. Southern California Law Review.

Dewiel, Boris, 2000, Democracy, A History of Ideas, UBC Press.

Fakih, Mansour, 2006, Runtuhnya Teori Pembanguna dan Globalisasi, Kerjasama Insist Press dan Pustaka Pelajar, Yogyakarta.

Forum for Democratic Reform, 2000, Democratization in Indonesia: An Assessment, (Stockholm: International Institute for Democracy and Electoral Assistance).

Keraf, A. Sony Keraf, 2002, Etika Lingkungan, Kompas, Jakarta. Hal. 33.

Keraf, A. Sony, 2014, Filsafat Lingkungan Hidup. Alam sebagai Sebuah Sistem Kehidupan. Bersama Fritjof Capra, Kanisius, Yogyakarta.

Keraf, A. Sony, dan Mikhael Dua, 2001, Ilmu Pengetahuan. Sebuah Tinjauan Filosofis, Kanisius, Yogyakarta.

Komisi Dunia untuk Lingkungan Hidup dan Pembangunan (World Commissions on Environmental and Development), 1988, Hari Depan Kita Bersama, Gramedia, Jakarta.

Leibniz Center for Tropical Marine Ecology (ZMT), Fahrenheitstraße 6, 28359 Bremen, Germany., Marine pollution bulletin (Impact Factor: 2.63). 03/2011; 62(4).

Li, Quan dan Rafael Reuveny, 2006, Democracy and Environmental Degradation International Studies Quarterly.

Megantara, Erri N., Pendekatan Pembangunan Antroposentris vs Ekosentris, Koran Republika, 11 Januari 1997.

Mukhlish dan Mustafa Lutfi, 2011, Ekologi Konstitusi: Antara Rekosntruksi, Investasi atau Eksploitasi atas Nama NKRI, Jurnal Mahkamah Konstitusi, Vol. 8 No. 3.

Priyatna, Maret, Penerapan Konsep Konstitusi Hijau (Green Constitution) di Indonesia sebagai Tanggung Jawab Negara dalam Perlindungan dan Pengelolaan Lingkungan Hidup, Jurnal Konstitusi, Vol. 7 Nomor 4, Agustus 2010.

Santosa, Mas Achmad, 2001, Peran Reformasi Hukum dalam Mewujudkan Good Environmental Governance, dalam Good Governance dan Hukum Lingkungan, ICEL, Jakarta.

Santosa, Mas Achmad, 2009, dalam Pengantar Jimly Asshidiqqie, Green Constitution: Nuansa Hijau Undang-undang Dasar Negara Republik Indonesia Tahun 1945, Rajawali Press, Jakarta. 
Santosa, Mas Achmad, Greener Conctitution: Solusi Pengarusutamaan Pembangunan Berkelanjutan, dalam Iwan J. Azis, et al. (Ed.), 2010, Pembangunan Berkelanjutan: Peran dan Kontribusi Emil Salim, Gramedia.

Shiva, Vandana, 2005, Earth Democracy: Justice, Sustainablity, and Peace, South End Press, Cambridge.

Sudjito, 2013, Hukum dalam Pelangi Kehidupan, edisi revisi, Tugu Jogja Pustaka, Jogjakarta.

Triana, Nita, Elly Kristiani P., 2004, Alternative Dispute Resolution/ADR (Pelaksanaan Penegakan Hukum Lingkungan Dengan Konsep ADR Dalam Kasus Pencemaran Laut Oleh Kapal King Fisher, Penelitian Dosen Muda, DIKTI.

Undang-undang Dasar 1945

Undang-undang Nomor 23 Tahun 1997 tentang Pengelolaan Lingkungan Hidup

Undang-undang Nomor 32 Tahun 2009 tentang Perlindungan dan Pengelolaan Lingkungan Hidup

Undang-undang Nomor 4 Tahun 1982 tentang Lingkungan Hidup Tahun 